\title{
WEST INDIAN CARABID $\approx$ VI. THE JAMAICAN SPECIES, AND THEIR WINGS
}

\author{
By P. J. DARLington JR. \\ Museum of Comparative Zoölogy
}

This paper is the sixth of my series on the carabid beetles of the West Indies. It is the first comprehensive treatment of the Carabidæ of Jamaica. All known Jamaican species (80) are listed taxonomically, and the list is annotated with data on the insects' wings and flight. At the end of the list, the distribution of flying and flightless species in Jamaica is summarized and discussed. The facts here put on record concerning the atrophy of wings of certain species in the mountains of Jamaica will be referred to again in a paper which I have in manuscript, on the wings of Carabidæ of mountains and islands.

The Museum of Comparative Zoölogy possesses a good representation of Jamaican Carabidæ collected by Mr. A. E. Wight, Prof. C. T. Brues, Mr. Chester Roys, and myself, and by some other persons. Besides this, I have had for study as a loan from the United States National Museum about 320 specimens of Carabidæ collected in Jamaica by Dr. E. A. Chapin and Dr. R. E. Blackwelder during the winter of 1937. This borrowed collection really provided the stimulus which has called forth the present paper. It adds several genera and species to the Jamaican list, and contains also numerous specimens taken "flying at dusk" in nets attached to automobiles. Records of species taken actually in flight are unusual, and are very interesting in connection with my studies of Carabid wings.

Species included in the following list without exact locality data are known in Jamaica only from the lowlands, below $1,000 \mathrm{ft}$. altitude, or are known merely from "Jamaica," presumably from low altitudes. Species noted as "winged" have the inner wings fully developed and apparently fitted for flight in one or more Jamaican specimens. 


\section{LIST OF THE CARABIDE OF JAMAICA}

1. Calosoma alternans alternans (Fab.). Winged.

2. Pachyteles sp. Blue Mt. Peak, Dec. 13, 1890 (unique in M. C. Z.; collector unknown). This specimen has been submitted to Mr. M. Bänninger, who is not yet ready to describe it. Flightless; wings vestigial.

3. Distichus granulipygus Bts. Winged.

4. Clivina dentipes Dej. Winged.

5. Clivina insularis (J.-D.). Winged.

6. Clivina biguttata Putz. Winged.

7. Oxydrepanus rufus (Putz.). Winged; "flying at dusk" (Chapin \& Blackwelder).

8. Schizogenius arimao Darl. Winged.

9. Bembidion jamaicense Darl. Slopes of Blue Mts. up to about 4,500 ft., along streams. Winged.

10. Bembidion darlingtoni Mutch. Winged.

11. Bembidion sparsum (Bts.). Winged; flies actively.

12. Bembidion chevrolati (G. \& H.). Winged.

13. Bembidion fastidiosum (Laf.). Winged.

14. Pericompsus blandulus Schm. Winged.

15. Tachys occultator Csy. (provisional det.). Winged.

16. Tachys bradycellinus Hayw. Winged.

17. Tachys carib Darl. In Jamaica, from near sea level to about $4,500 \mathrm{ft}$. altitude, by streams. Winged ; "flying at dusk" (C. \& B.).

18. Tachys abruptus Darl. In Jamaica, from sea level to about 4,500 ft. altitude, usually by streams. Winged.

19. Tachys trechulus Darl. Known only from the types from Blue Mt. Forest Reserve, 5,000-7,000 ft., under deeply buried stones in damp cloudforest, not by streams. Flightless, wings vestigial.

20. Tachys filax Darl. Winged; "flying at dusk" (C. \& B.).

21. Tachys pumilus (Dej.). Winged.

22. Tachys striax Darl. Winged; "flying at dusk" (C. \& B.).

23. Tachys cubax Darl. Winged; "flying at dusk" (C. \& B.).

24. Tachys vorax Lec. Winged.

25. Tachys proximus (Say). A single of in the Chapin and Blackwelder collection is the first specimen of this North American species to be found in the West Indies. Winged. 
26. Tachys scitulus Lec. Winged.

27. Tachys (near) corruscus Lec. Winged; "flying at dusk" (C. \& B.).

28. Limnastis capito Bts. Winged; "flying at dusk" (C. \& B.).

29. Micratopus insularis Darl. Winged.

30. Perileptus jeanneli Darl. Near sea level to 4,500 ft., by swift streams. Winged; "flying at dusk" (C. \& B.).

31. Perileptus minutus Darl. Winged.

32. Panagæus quadrisignatus Chev. Winged.

33. Morion georgiæ (Beauv.). Winged.

34. Morion costigerus Darl. Known only from Cinchona in the Blue Mts., at about 5,000 ft. altitude, in rotten wood and under loose bark of dead trees. Flightless, wings vestigial.

35. Agonum extensicolle cubanum Darl. Winged.

- Colpodes. This is the principal genus of mountaininhabiting Carabidæ in the West Indies: 50 species have been found in the Greater Antilles, almost all at considerable altitudes. A few of the species are winged, but the majority are flightless, with atrophied wings. Wing atrophy has evidently occurred independently in several different Antillean stocks of the genus.

36. Colpodes cinchonæ Darl. Known only from localities in the Blue Mts., at and above 5,000 ft., under various cover in damp forest. Wings vestigial.

37. Colpodes faber Darl. Known only from Blue Mt. Forest Reserve, 5,000-6,000 ft., under cover in wet forest, but (like most other Colpodes) not by open water. Wings vestigial, elytra ankylosed.

38. Colpodes vagepunctatus Darl. Known definitely only from Newton, 3,000 ft. Flightless, wings reduced.

39. Colpodes macer Darl. Known from Mandeville (probably mountains near), and from Cinchona in the Blue Mts., 5,000 ft. altitude. Wings vestigial.

40. Colpodes subovalis Darl. Known only from Blue Mt. Forest Reserve, about 5,000 ft., in rotten logs and piles of dead vegetation in damp forest. Flightless, wings reduced. 
41. Colpodes bromeliarum Darl. From near Bath and Portland, at 300 and 1,000 ft. altitude, in epiphytic bromeliads. Winged.

42. Colpodes roysi Darl. Near Bath, in an epiphytic bromeliad. Winged.

43. Colpodes punctus Darl. Known only from Cinchona in the Blue Mts., at 5,000 ft.; habits unknown, but relationship to two preceding species suggests life in epiphytes. ${ }^{1}$ Winged.

44. Colpodes bruesi Darl. Known only from Newton, 3,000 ft.; also a member of the bromeliarum group. Winged.

45. Colpodes $s p$. (Van Emden MS). Known only from Hartham; apparently another bromeliad species, the most highly specialized in structure of the group. Apparently winged (I have seen a specimen of this species, but did not examine the wings).

46. Colpodes rquinoctialis (Chd.). In Jamaica, on slopes of the Blue Mts. below 4,500 ft., along large streams. Winged.

47. Colpodes latelytra Darl. Known from a unique from Portland Gap, Blue Mt. Forest Reserve, 5,000 ft., from a pile of recently cut grass; the species may be arboreal. Winged.

48. Lachnophorus leucopterus Chev. Lowlands and slopes of Blue Mts. below 4,500 ft., by streams. Winged, flies actively.

49. Anchonoderus subtilis Bts. Winged, flies actively.

50. Euphorticus pubescens (Dej.). Winged.

51. Perigona nigriceps (Dej.). Winged, "fiying at dusk" (C. \& B.).

52. Chlænius jamaicæ Darl. Winged.

53. Stenous duodecimstriatus (Chev.). Winged.

54. Stenous tibialis (Chev.). Winged.

55. Selenophorus flavilabris flavilabris Dej. Winged.

56. Selenophorus chalybeus Dej. Winged.

57. Selenophorus alternans Dej. Winged.

1Since this was written, I have seen specimens of punctus in the Philadelphia Academy, collected by Mr. J. A. G. Rehn, definitely "from epiphytic bromeliads", "in mountain forest" at 4,980 and 5,600 ft. in the Blue Mts. 
58. Selenophorus sinuatus (Gyll.). Winged.

59. Selenophorus discopunctatus Dej. Winged.

60. Selenophorus puncticollis Putz. Winged.

61. Selenophorus aeneocupreus Dej. Winged.

62. Selenophorus nonseriatus Darl. Winged.

63. Bradycellus cubanus Darl. Winged.

64. Bradycellus velatus Darl. Winged.

65. Acupalpus (Stenolophus) ochropezus (Say). Winged, "flying at dusk" (C. \& B.).

66. Masoreus brevicillus Chev. Winged.

67. Lebia bitaeniata Chev. Winged.

68. Lebia cyanea Dej. Winged.

69. Lebia abdominalis Chd. Winged.

70. Microlestes poeyi (J.-D.). The single Jamaican specimen I have seen is winged, but poeyi has dimorphic wings in Cuba.

71. Apenes marginalis (Dej.). Winged.

72. Apenes coriacea (Chev.). Winged.

73. Apenes parallela (Dej.). Winged.

74. Apenes aptera Darl. Known only from Blue Mts., 5,000-7,000 ft., under stones in damp forest. Wings vestigial.

75. Pentagonica flavipes picipes Darl. Winged.

76. Colliuris tetrastigma Chd. Winged; related species fly actively.

77. Colliuris limbatus (Waterh.). This is the only species of Carabidæ recorded from Jamaica which is unknown to me. It is probably related to $C$. picta (Chd.), and is probably winged.

78. Pseudaptinus apicalis Darl. Winged.

79. Pseudaptinus insularis Mutch. Winged.

80. Pseudaptinus dorsalis (Brullé). Winged.

Of the 80 species of Carabidæ listed from Jamaica, some 63 occur in the lowlands, below 1,000 ft. altitude. All of these 63 species, in all the diverse lowland habitats, are winged. Some of them are known to fly well, and it is likely that all, or almost all, fly occasionally.

The middle slopes of the Jamaican mountains, above 1,000 and below 5,000 ft., have not yet been very thoroughly collected for beetles, but a certain number of Carabidæ have been found there. Most are winged. Half a dozen or so winged riparian species follow the mountain brooks up to an alti- 
tude of about 4,500 $\mathrm{ft}$., which is about as high as there are brooks in the Jamaican mountains. Some of the same species occur also along lowland streams; others are confined to the banks of the mountain torrents. Two or more winged Colpodes of the bromeliarum group occur on the mountain slopes, and probably live between the leaf bases of broad-leaved, pineapple-like bromeliads, in trees. And other winged Carabidæ, some of them lowland species but others perhaps peculiar, are to be expected in proper habitats on the lower and middle mountain slopes.

With increasing altitude, a few flightless Carabidæ, with reduced or vestigial wings, begin to appear among the winged ones, and from the 5,000 ft. level to the highest summit $(7,388 \mathrm{ft}$.) flightless species predominate. Ten species of Carabidæ have been found at or above 5,000 ft. in the Jamaican mountains. Only 2 of the these species, both perhaps arboreal, have fully developed wings. The other 8 species have reduced or vestigial wings, and are flightless. They live chiefly or entirely on the ground in damp cloudforest.

Of course, there is still much to be learned about the details of distribution of Carabidæ in Jamaica, but the main pattern is already very clear. In the lowlands, there is a rather numerous and diverse fauna of Carabidæ, all winged. On the middle slopes of the mountains, there is a smaller, mixed, transition fauna. And at highest altitudes there is a small fauna which is predominantly flightless.

Similar conditions are found throughout the Greater Antilles ( $c f$. Darlington, Memorias de la Sociedad Cubana de Historia Natural 13, 1939, pp. 79-80). Throughout the lowlands of each island are found numerous and diverse Carabidæ, all or nearly all of which are winged. But wherever mountains rise above 5,000 ft. a few endemic, alticoline, flightless species occur, most of them apparently derived in situ, independently on the different mountain tops, from winged ancestors.

This is not an accidental phenomenon. It appears to be the result of the action of powerful environmental forces. But it is difficult to say just what the forces are, for they are complex as well as powerful. I shall try to deal with them in another paper. 

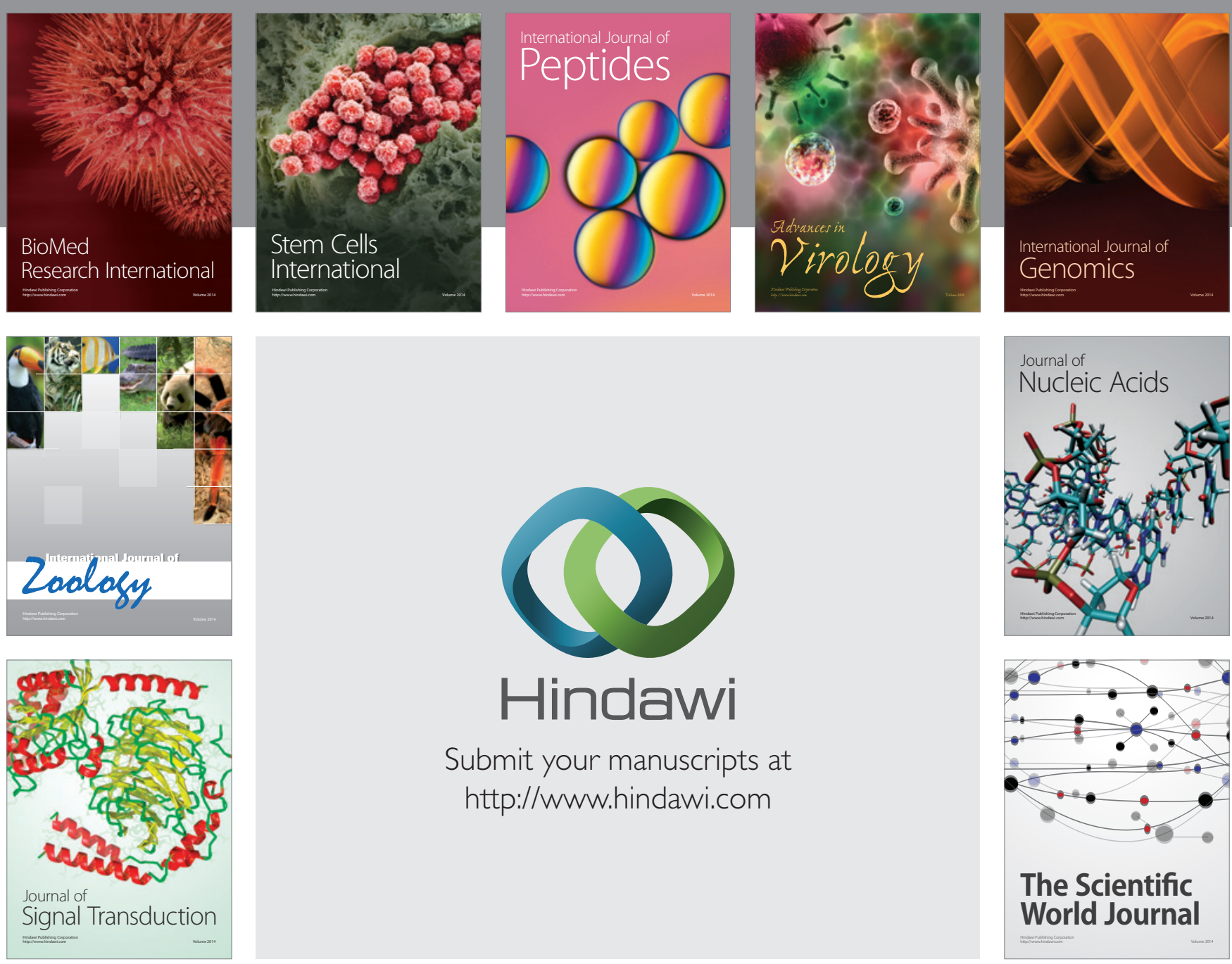

Submit your manuscripts at

http://www.hindawi.com
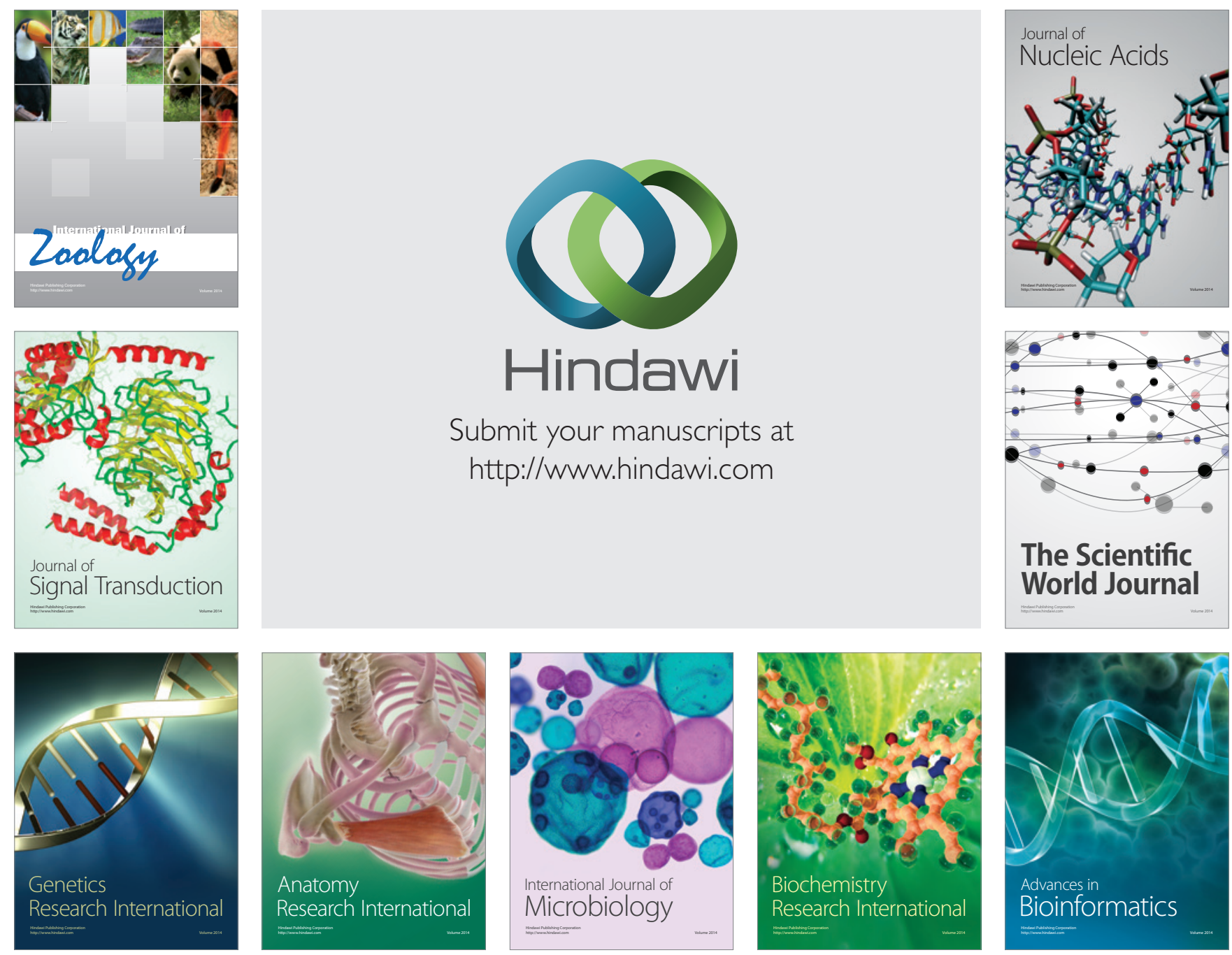

The Scientific World Journal
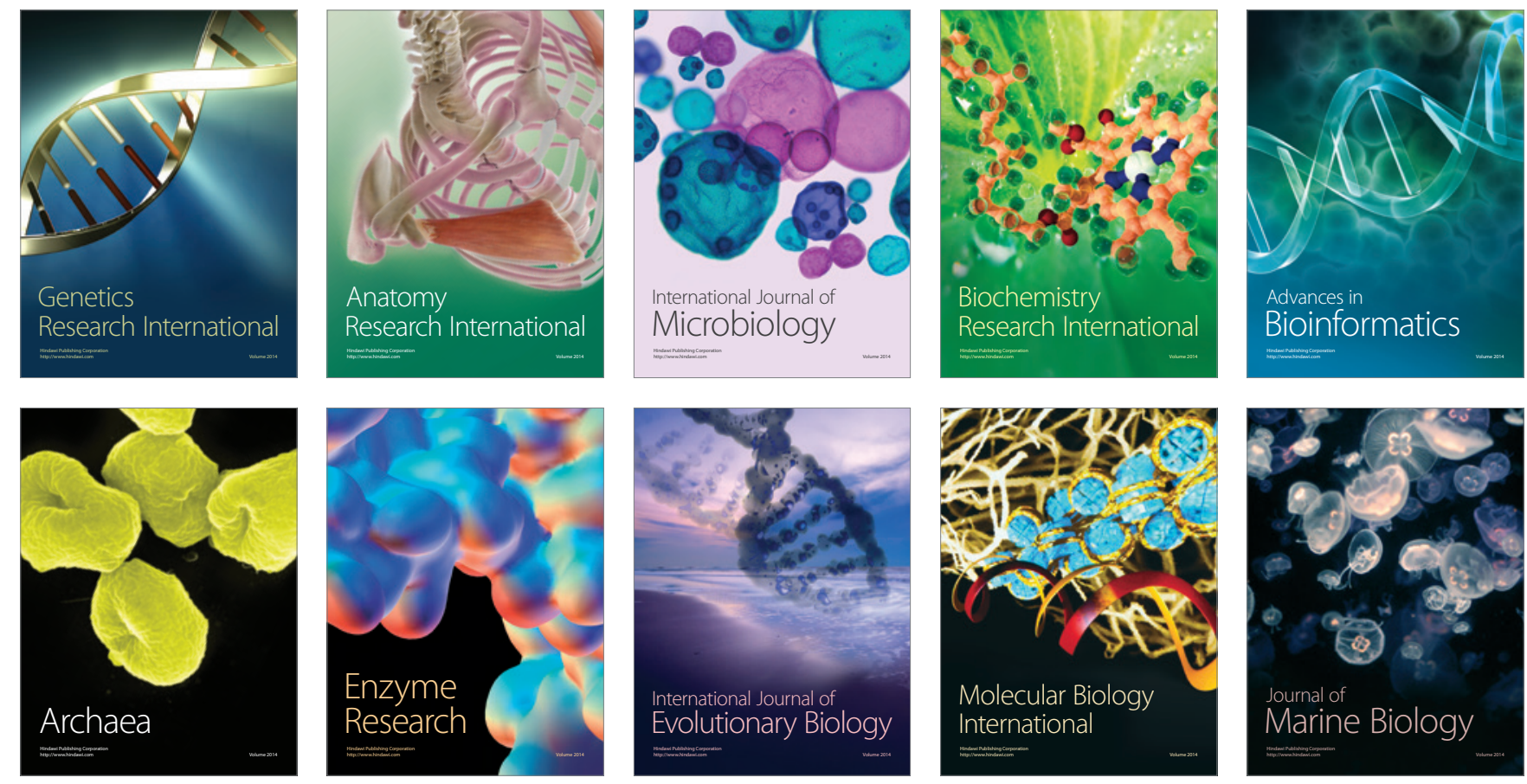